\title{
Lymph-borne CD8 $\alpha^{+}$dendritic cells are uniquely able to cross-prime CD ${ }^{+}$T cells with antigen acquired from intestinal epithelial cells
}

\author{
V Cerovic $^{1}$, SA Houston ${ }^{1}$, J Westlund ${ }^{2}$, L Utriainen ${ }^{1}$, ES Davison ${ }^{1}$, CL Scott $^{1}$, CC Bain ${ }^{1}$, T Joeris ${ }^{3}$, \\ WW Agace ${ }^{3,4}$, RA Kroczek ${ }^{5}$, AM Mowat ${ }^{1}$, U Yrlid $^{2}$ and SWF Milling ${ }^{1}$
}

Cross-presentation of cellular antigens is crucial for priming CD8 ${ }^{+} \mathrm{T}$ cells, and generating immunity to intracellular pathogens-particularly viruses. It is unclear which intestinal phagocytes perform this function in vivo. To address this, we examined dendritic cells (DCs) from the intestinal lymph of IFABP-tOVA 232-4 mice, which express ovalbumin in small intestinal epithelial cells (IECs). Among lymph DCs (LDCs) only CD103 ${ }^{+}$CD11b ${ }^{-}$CD8 $\alpha^{+}$DCs cross-present IEC-derived ovalbumin to $\mathrm{CD}^{+}$OT-I T cells. Similarly, in the mesenteric lymph nodes (MLNs), cross-presentation of IEC-ovalbumin was limited to the $\mathrm{CD} 11 \mathrm{c}^{+} \mathrm{MHCI}^{\mathrm{hi}} \mathrm{CD} 8 \alpha^{+}$migratory DCs, but absent from all other subsets, including the resident CD8 $\alpha^{\text {hi }}$ DCs. Crucially, delivery of purified CD8 $\alpha^{+}$LDCs, but not other LDC subsets, into the MLN subcapsular lymphatic sinus induced proliferation of ovalbumin-specific, gut-tropic CD8 ${ }^{+}$Tcells in vivo. Finally, in 232-4 mice treated with R848, CD8 $\alpha^{+}$LDCs were uniquely able to cross-prime interferon $\gamma$-producing CD8 ${ }^{+}$Tcells and drive $^{2}$ their migration to the intestine. Our results clearly demonstrate that migrating CD $8 \alpha^{+}$intestinal DCs are indispensable for cross-presentation of cellular antigens and, in conditions of inflammation, for the initial differentiation of effector $\mathrm{CD}^{+} \mathrm{T}$ cells. They may therefore represent an important target for the development of antiviral vaccinations.

\section{INTRODUCTION}

Cross-presentation is the process by which exogenous antigens are displayed on major histocompatibility complex (MHC) class I molecules to $\mathrm{CD} 8^{+} \mathrm{T}$ cells and is necessary for the generation of cytotoxic T-cell (CTL) responses against tumors and intracellular pathogens, such as viruses. It has long been recognized that the capacity to cross-present is limited to a relatively small population of dendritic cells (DCs). In murine lymphoid tissues these cells are characterized by expression of CD8 $\alpha .{ }^{1}$ Cross-presenting lymphoid tissue CD8 $\alpha^{+}$DCs also have a high capacity for uptake of apoptotic cells, ${ }^{2}$ and, in conditions of inflammation, initiate the differentiation of naive $\mathrm{CD}^{+} \mathrm{T}$ cells into CTLs in a process known as crosspriming. ${ }^{3,4}$ Cross-presentation by non-lymphoid "peripheral" tissue DCs is less well understood. It was suggested that peripheral DCs are unable to directly cross-present antigen after migrating to the draining lymph nodes (LNs), ${ }^{5}$ and merely serve to transfer peripheral antigen to $\mathrm{CD} 8 \alpha^{+}$lymphoid tissueresident DCs. More recently, a subset of $\mathrm{CD}_{103}{ }^{+}$DCs, which share ontogeny with lymphoid tissue CD $8 \alpha^{+}$DCs, were shown to take up antigen in the lung and skin and, after activation, to cross-prime $\mathrm{CD} 8{ }^{+} \mathrm{T}$ cells in the draining LNs. ${ }^{6,7}$

The identification of cells capable of cross-priming in the intestinal mucosa remains controversial. Intestinal macrophages are able to capture and cross-present soluble antigen ${ }^{8}$ but are absent from intestinal lymph ${ }^{9,10}$ and are therefore unlikely to initiate priming of naive T cells in mesenteric LNs (MLNs). Intestinal $\mathrm{CD}_{103}{ }^{+}$lamina propria (LP) DCs can be separated into $\mathrm{CD} 8 \alpha^{+}$and $\mathrm{CD} 8 \alpha^{-}$subsets, both of which are capable of initiating CTL differentiation after incubation with soluble antigen in vitro. ${ }^{11}$ Although it was suggested that $\mathrm{CD} 8{ }^{+}$ intestinal DCs derive exclusively from Peyer's patches and are

\footnotetext{
${ }^{1}$ Centre for Immunobiology, Institute for Infection, Immunity \& Inflammation, College of Medical, Veterinary and Life Sciences, University of Glasgow, Glasgow, UK. ${ }^{2}$ Department of Medical Microbiology and Immunology, University of Gothenburg, Gothenburg, Sweden. ${ }^{3}$ Immunology Section, Department of Experimental Medical Science, Lund University, Lund, Sweden. ${ }^{4}$ Department of International Health, Immunology and Microbiology, University of Copenhagen, Copenhagen, Denmark and ${ }^{5}$ Department of Molecular Immunology, Robert Koch-Institute, Berlin, Germany. Correspondence: V Cerovic (vuk.cerovic@glasgow.ac.uk) 
unlikely to migrate to MLNs, ${ }^{12}$ we have demonstrated that $\mathrm{CD} 8 \alpha^{+}$DCs continuously migrate in intestinal lymph. In fact, they are abundant even in the intestine and lymph of mice lacking all intestinal lymphoid tissues, indicating that the majority of $\mathrm{CD} 8 \alpha^{+}$intestinal DCs derive from the LP of the conventional villus mucosa. ${ }^{10}$ In addition to the two subsets of $\mathrm{CD}_{103}{ }^{+}$DCs, a detailed survey of intestinal lymph DCs (LDCs) revealed subsets of bona fide $\mathrm{CD} 103^{-}$intestinal DCs. Notably, all $\mathrm{CD}_{103}{ }^{+}$and $\mathrm{CD} 103^{-}$LDC subsets were able to cross-present soluble antigen in vitro. ${ }^{10}$ It is not currently clear which of these DC populations is responsible for crosspresentation of intestinal antigen and priming of CTL responses in vivo. Crucially, soluble antigens have been used by the majority of studies to date; this does not represent the physiological source of antigen involved in cross-priming CTLs. Cross-priming of virus-specific $\mathrm{CD} 8{ }^{+} \mathrm{T}$ cells requires presentation of cell-associated antigens. ${ }^{6,13}$ Therefore, it is of vital importance to unambiguously characterize the populations involved in the cross-presentation of cellular antigens and the initiation of CTL responses.

Here we use transgenic mice that express intracellular ovalbumin (OVA) only in mature intestinal epithelial cells (IECs), ${ }^{14}$ to assess the capacity of intestinal DC subsets to capture cellular antigens and prime $\mathrm{CD} 8{ }^{+} \mathrm{T}$ cells. Interestingly, we find that cross-presentation of IEC-expressed OVA in the MLNs is entirely dependent on the $\mathrm{CD} 103^{+} \mathrm{CD} 8 \alpha^{+}$ migratory DC population, and absent from all other intestinal and MLN DC subsets. Furthermore, we demonstrate that the $\mathrm{CD} 103^{+} \mathrm{CD} 8 \alpha^{+}$subset of migrating intestinal DCs is both necessary and sufficient to induce proliferation of gut-tropic $\mathrm{CD}^{+} \mathrm{T}$ cells in vivo in response to IEC antigen. Finally, we show that under inflammatory conditions the $\mathrm{CD} 103^{+}$ $\mathrm{CD} 8 \alpha^{+}$subset of intestinal lymph DCs induces cross-priming of naive $\mathrm{CD}^{+} \mathrm{T}$ cells, driving their differentiation into interferon $\gamma$ (IFN- $\gamma$ )-producing effector cells. These data demonstrate, for the first time, the unique abilities of migratory intestinal $\mathrm{CD} 8 \alpha^{+}$DCs to acquire and transport intracellular IEC-derived antigen from the intestine and to directly drive the initial differentiation of naive T CD8 ${ }^{+} \mathrm{T}$ cells into effector cells.

\section{RESULTS}

IEC-expressed OVA is efficiently presented to $\mathrm{CD}^{+}{ }^{+} \mathrm{T}$ cells The majority of data on the cross-presenting ability of intestinal DCs concerns their uptake and presentation of soluble antigen. However, following infection with intracellular pathogens that do not infect antigen-presenting cells directly, cross-presentation of cell-associated antigens is essential. Hence we used IFABP-tOVA 232-4 (232-4) mice, which express OVA as an intracellular antigen exclusively in mature IECs. When transferred into steady-state 232-4 mice, transgenic OVAspecific OT-I CD8 ${ }^{+} \mathrm{T}$ cells proliferate and migrate to the intestinal LP, but do not mediate killing of OVA-expressing IECs. ${ }^{14}$ However, in the presence of an inflammatory stimulus, delivered by viral infection or addition of adjuvant, OT-I cells transferred into 232-4 mice differentiate into CTLs and mediate destruction of the intestinal epithelium. ${ }^{14,15}$ Similarly, we find that this differentiation of OT-I cells into CTLs also occurs after treatment of recipient 232-4 mice with R848, a Toll-like receptor 7 (TLR7) agonist. 232-4 animals that receive OT-I cells and R848 develop small intestinal inflammation characterized by weight loss (Figure 1a), prodigious infiltration of $\mathrm{CD} 8^{+}$ $\mathrm{T}$ cells (Figure 1b), destruction of the epithelial-cell layer (Figure 1c), shortening of the villi (Figure 1d), and high levels of IFN- $\gamma$ in serum (Figure 1e). Therefore, 232-4 animals can be used to investigate mechanisms involved in the crosspresentation of IEC antigen, and the induction of effector $\mathrm{CD}^{+} \mathrm{T}$-cell responses in vivo.

\section{Only $\mathrm{CD}_{103}{ }^{+} \mathrm{CD}_{11 \mathrm{~b}}{ }^{-} \mathrm{CD} 8 \alpha^{+}$migrating DCs present IEC antigen to $\mathrm{CD}^{+} \mathrm{T}$ cells}

Since IEC-expressed OVA is efficiently cross-presented to OT-I $\mathrm{CD}^{+}$T cells, we used the 232-4 mice to determine which DC populations are able to capture, transport, and present this antigen. In order to identify and purify all migratory DC populations in lymph, unequivocally and without bias, we purified by fluorescence-activated cell sorting the four distinct LDC subsets that are obtained after thoracic duct cannulation of mesenteric lymphadenectomized (MLNx) mice (Figure 2a). This technique allows the collection of all DCs that would normally migrate from the intestine to the MLNs, without contamination by DCs from other tissues. ${ }^{10}$ All four subsets of intestinal LDCs from wild-type mice cross-presented soluble OVA to OT-I CD8 ${ }^{+}$T cells (Figure $2 \mathbf{b}$ ). In contrast, when the LDC subsets were purified from 232-4 mice and co-cultured with OT-I cells without addition of soluble OVA, only the $\mathrm{CD}_{103}{ }^{+} \mathrm{CD}_{11 b^{-}}$DCs could cross-present IEC-associated antigen in vitro (Figure $2 \mathrm{c}$ ).

Several reports suggest that the capacity to cross-present in LNs is limited to a subset of CD $8 \alpha$-expressing DCs, which are assumed to be blood derived and LN resident. ${ }^{12,16}$ However, our results indicate that migrating lymph-borne $\mathrm{CD} 103^{+}$ $\mathrm{CD}_{11 \mathrm{~b}}{ }^{-}$DCs are able to directly present IEC-derived antigen to $\mathrm{T}$ cells. In order to compare the relative contributions of migratory and resident MLN DCs to cross-presentation, we purified the migratory $\left(\mathrm{CD} 11 \mathrm{c}^{+} \mathrm{MHCII}^{\mathrm{hi}}\right)$ and $\mathrm{LN}$-resident DCs $\left(\mathrm{CD} 11 \mathrm{c}^{\mathrm{hi}} \mathrm{MHCII}^{+}\right.$) from the MLNs of 232-4 mice (Figure 3a), using a strategy that has been previously described. ${ }^{17}$ To ensure that plasmacytoid DCs did not contaminate these purified populations, $\mathrm{B}_{2} 20^{+}$cells were also excluded from the cell sorts. As we have previously observed in lymph, the migratory $\mathrm{CD} 103^{+} \mathrm{CD} 1 \mathrm{~b}^{-}$DCs express $\mathrm{CD} 8 \alpha,{ }^{10}$ albeit at lower levels than the MLN-resident CD11b ${ }^{-}$DCs (Figure 3b). The purified migratory and resident MLN DCs were then cultured with OT-I T cells. We found that the ability to cross-present was entirely contained within the $\mathrm{CD} 103^{+}$ $\mathrm{CD}_{11 b^{-}}$population of the migratory CD11c ${ }^{+} \mathrm{MHCII}^{\mathrm{hi}} \mathrm{MLN}$ DCs, and was absent from the "resident" CD $8 \alpha^{+} \mathrm{CD} 11 b^{-}$ DCs (Figure 3c,d). CD11b ${ }^{+}$subsets of both migratory and resident DCs had no cross-presenting activity in these experiments. Consistent with these results, we also observed that when LP DCs from 232-4 mice were co-cultured with OT-I 

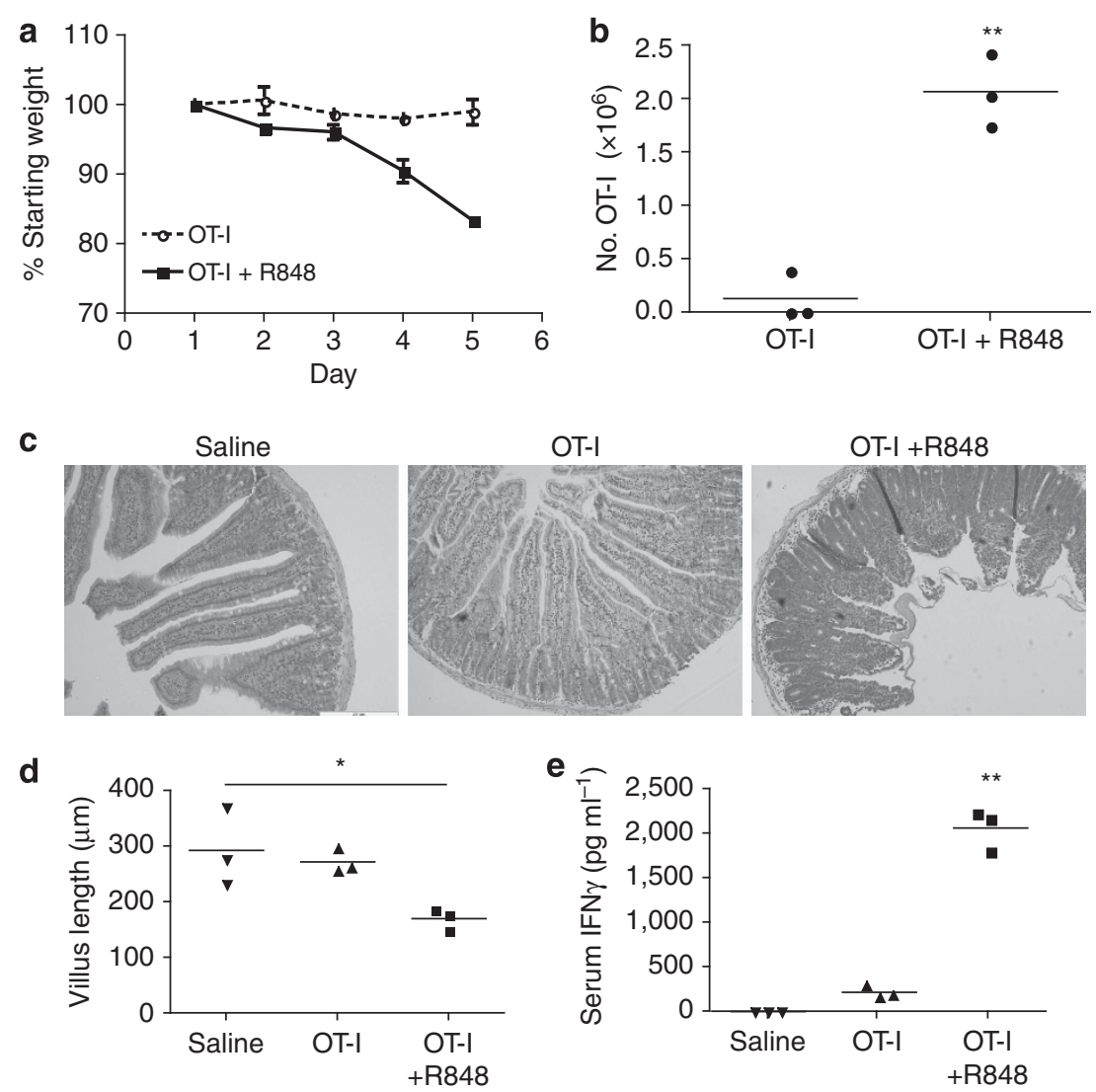

Figure 1 Stimulation with R848 after transfer of OT-I cells into IFABP-tOVA 232-4 (232-4) mice causes intestinal inflammation. 232-4 mice were injected intravenously with $5 \times 10^{6} \mathrm{CD} 45.1^{+} \mathrm{OT}-\mathrm{I}$ cells, and a day later received R848 or phosphate-buffered saline intraperitoneally. (a) The mice were weighed daily, shown here as percentage of starting weight. Each point represents the mean of five biological replicates. (b) On day 5 , cells from the small intestinal lamina propria were stained for flow cytometry, and the number of CD45.1 ${ }^{+}$OT-I cells determined. (c) Sections of small intestine from mice injected with OT-I cells, OT-I cells and R848, or with saline alone, were stained with hematoxylin and eosin to observe the pathology. (d) The mean villus length in the jejunum was calculated after measuring at least 50 villi from each animal. (e) Serum samples were obtained 5 days after R848 administration, and the levels of serum IFN- $\gamma$ were determined by ELISA. In all panels asterisks denote statistical significance $\left({ }^{\star} P<0.05,{ }^{\star \star} P<0.01\right)$. ELISA, enzymelinked immunosorbent assay; IFN- $\gamma$, interferon $\gamma$.

cells, only the $\mathrm{CD} 03^{+} \mathrm{CD}^{+11 b^{-}}$DCs were able to crosspresent IEC-derived OVA to the OT-I cells (Supplementary Figure S1 online).

In order to eliminate the possibility that 232-4 DCs can express and present endogenous OVA, we used a bone marrow chimera approach. In bone marrow chimeric mice where OVA is only expressed in the non-hematopoietic compartment, donor wild-type $\mathrm{CD}_{103}{ }^{+} \mathrm{CD}_{11 \mathrm{~b}}{ }^{-}$MLN DCs efficiently cross-presented OVA to OT-I cells. However, when 232-4 bone marrow was transplanted into wild-type recipients, donor MLN DCs were not able to induce OT-I proliferation (Supplementary Figure S2). Therefore, the induction of OT-I proliferation was entirely due to cross-presentation of IEC-derived OVA, and not due to OVA expression in the DCs themselves. Finally, in order to test whether we can directly observe IEC-associated antigen in any of the MLN DC subsets, we adapted a technique for detecting vesicles containing epithelial-cell cytokeratin in DCs. ${ }^{18}$ Discrete cytokeratin ${ }^{+}$ inclusions were observed in flow-sorted DC cytospin preparations and were significantly more frequent in the migratory
$\mathrm{CD}_{103}{ }^{+} \mathrm{CD}_{11 \mathrm{~b}^{-}}$DCs compared to other MLN DC subsets (Figure 3e,f).

These results demonstrate that only a single subset of intestinal DCs-the migratory $\mathrm{CD} 11 \mathrm{c}^{+} \mathrm{MHCII}^{\mathrm{hi}} \mathrm{CD} 103^{+}$ $\mathrm{CD}_{11 \mathrm{~b}}{ }^{-} \mathrm{CD} 8 \alpha^{+} \mathrm{DCs}-$ is able to cross-present IEC-derived antigen in the MLNs.

\section{Intestinal $\mathrm{CD} 103^{+} \mathrm{CD} 1 \mathrm{~b}{ }^{-} \mathrm{CD} 8 \alpha^{+}$migrating $\mathrm{DCs}$ are phenotypically and ontogenically similar to other cross- presenting DC populations}

Cross-presenting DC populations in the spleen, LNs, and lung share several important characteristics, including the surface expression of DNGR-1 $1^{19,20}$ and XCR $1^{21,22}$ and a requirement for Batf3 and IRF8 in their development. ${ }^{16}$ In order to assess whether the cross-presenting migratory intestinal $\mathrm{CD}_{103}{ }^{+}$ $\mathrm{CD}_{11 \mathrm{~b}}{ }^{-} \mathrm{DCs}$ also display these properties, LDCs were examined for the expression of a range of surface markers by flow cytometry (Figure 4a). All subsets of LDCs lacked the expression of the macrophage markers MerTK, CD64, and CD14 but expressed the DC-specific markers CD26, CD24, and 
a
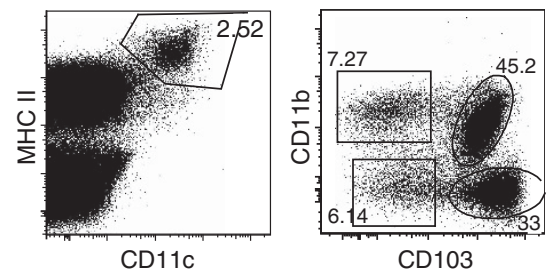

b

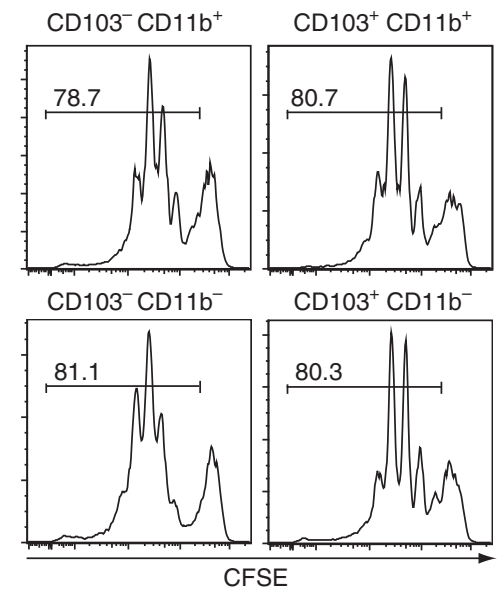

C
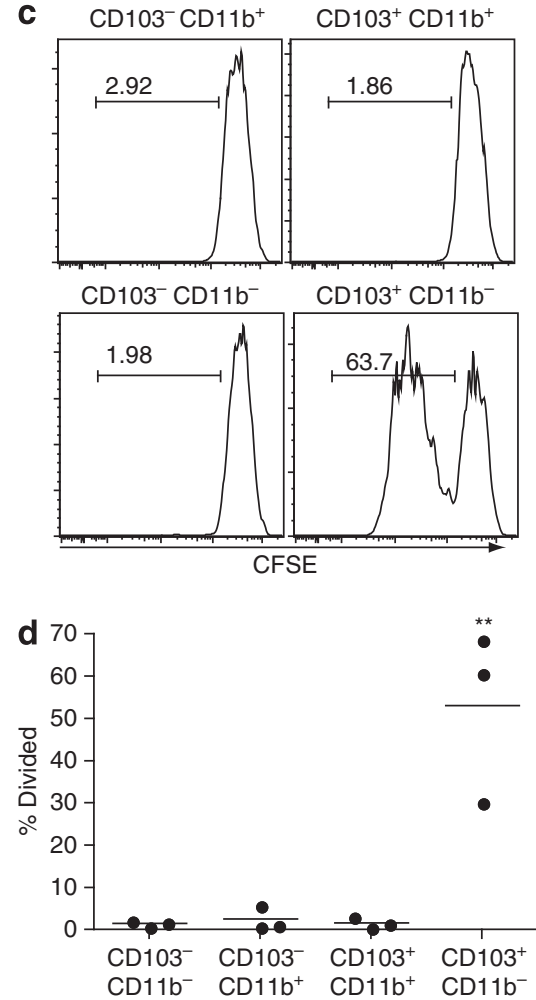

Figure 2 Intestinal epithelial-cell-expressed ovalbumin is cross-presented by migrating CD103 ${ }^{+} \mathrm{CD}_{11} \mathrm{~b}^{-}$lymph dendritic cells (LDCs). Thoracic duct cannulation was performed on 12-week-old mesenteric lymphadenectomized (MLNx) C57BI6 or IFABP-tOVA 232-4 (232-4) mice and lymph collected for $16 \mathrm{~h}$, on ice. Lymph cell populations were purified with fluorescence-activated cell sorting as shown in a. (b) 12,500 C57BI6 LDCs of the indicated subsets were pulsed with ovalbumin, then extensively washed. DCs were then co-cultured with $10^{5}$ carboxyfluorescein succinimidyl ester (CFSE)-labeled CD8 ${ }^{+}$ $\mathrm{CD}_{2} \mathrm{~L}^{+} \mathrm{OT}-\mathrm{I}$ cells for 3 days. Histograms represent proliferation as assessed by CFSE dilution. (c,d) 232-4 LDC subsets were plated out without the addition of soluble ovalbumin. The DCs' capacity to drive CD8 ${ }^{+}$T-cell proliferation was then assessed as above. (c) Histograms represent proliferation as assessed by CFSE dilution. (d) The graph shows the mean percentage of divided T cells; each dot represents an independent experiment. Asterisks denote statistical significance $\left({ }^{* *} P<0.01\right)$. MHC II, major histocompatibility complex class II molecules.

CD272. Compared with other subsets of intestinal LDCs, the $\mathrm{CD}_{103}{ }^{+} \mathrm{CD} 11 \mathrm{~b}^{-}$LDCs expressed the highest levels of CD272 and were unique in expressing high levels of $\mathrm{CD} 8 \alpha, \mathrm{XCR} 1$, and DNGR-1 (Clec-9A) and lacking expression of CD172a (Figure 4a). In order to examine whether migrating intestinal $\mathrm{CD}_{103}{ }^{+} \mathrm{CD}_{11 \mathrm{~b}}{ }^{-} \mathrm{CD} 8 \alpha^{+}$LDCs share ontogeny with cross-presenting populations in other tissues, we made use of Batf3 $3^{-1-}$ mice that lack lymphoid tissue-resident $\mathrm{CD} 8 \alpha^{+}$ DCs and intestinal $\mathrm{CD}_{103}{ }^{+} \mathrm{CD} 11 \mathrm{~b}{ }^{-}$DCs. ${ }^{16}$ As expected, thoracic duct lymph from MLNx Batf3 ${ }^{-/}$mice is significantly depleted of the $\mathrm{CD} 103^{+} \mathrm{CD} 11 \mathrm{~b}^{-} \mathrm{CD} 8 \alpha^{+} \mathrm{LDCs}$ (Figure 4b). The $\mathrm{CD} 103^{+} \mathrm{CD} 11 \mathrm{~b}^{-} \mathrm{CD} 8 \alpha^{+}$subset of LDCs also expressed significantly higher levels of Irf $8 \mathrm{mRNA}$ than the other lymph DC populations (Figure 4c). These results demonstrate that migrating intestinal $\mathrm{CD}_{103}{ }^{+} \mathrm{CD}_{11 b^{-}}$ $\mathrm{CD} 8 \alpha^{+}$LDCs share the ontogeny and many phenotypic characteristics with cross-presenting DCs in other tissues.

\section{Migratory intestinal CD103 ${ }^{+} \mathrm{CD} 11 \mathrm{~b}^{-} \mathrm{CD}^{-} \alpha^{+} \mathrm{DCs}$ are sufficient and necessary for cross-presentation of IEC antigen in the steady-state MLNs}

Previous studies have shown that in the absence of an inflammatory stimulus, OT-I CD8 ${ }^{+} \mathrm{T}$ cells in 232-4 mice recognize
IEC-derived OVA, proliferate, and acquire the capacity to migrate to the intestinal LP. However, they do not differentiate into IFN- $\gamma$-producing CTLs. ${ }^{14}$ To determine whether the $\mathrm{CD}_{103}{ }^{+} \mathrm{CD}_{11 b^{-}} \mathrm{CD} 8 \alpha^{+}$232-4 LDC subset alone was sufficient to cross-present IEC-derived antigen and drive this proliferation of naive $\mathrm{CD} 8{ }^{+} \mathrm{OT}-\mathrm{I}$ T cells in vivo, we used the approach outlined in Figure 5a. Briefly, carboxyfluorescein succinimidyl ester-labeled OVA-specific OT-I T cells were transferred intravenously into congenic wild-type mice. A day later, purified LDC populations from 232-4 mice were injected directly into the subcapsular lymphatic sinus of the MLNs (subcapsular injection). Three days later, LNs were collected and the transferred OT-I cells examined to determine whether any of the transferred DC subsets had induced their proliferation. Since no exogenous OVA was added in this system, any proliferation of OT-I T cells must result from the cross-presentation of IEC-derived OVA by the LDCs transferred into the MLNs from the 232-4 mice. OT-I cell proliferation was detected in the MLNs of mice that had received $\mathrm{CD}_{103}{ }^{+} \mathrm{CD} 11 \mathrm{~b}^{-} \mathrm{CD} 8 \alpha^{+} \mathrm{LDC}$, whereas all the other DC subsets were unable to stimulate OT-I proliferation (Figure 5b). This T-cell priming was localized, as no proliferation of transferred OT-I cells could be observed 
a

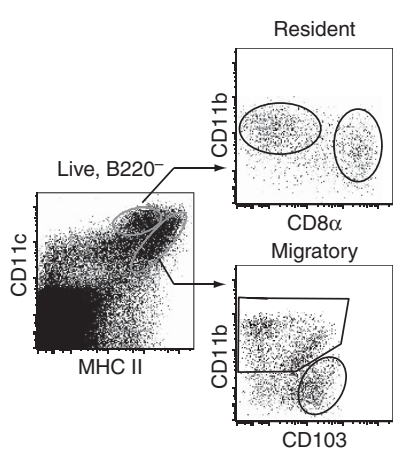

b

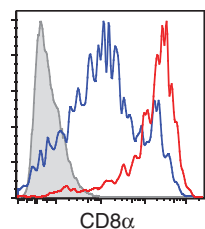

C
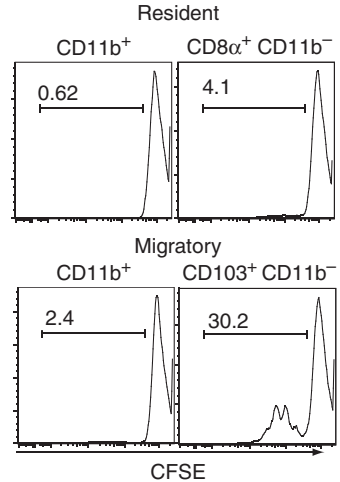

d

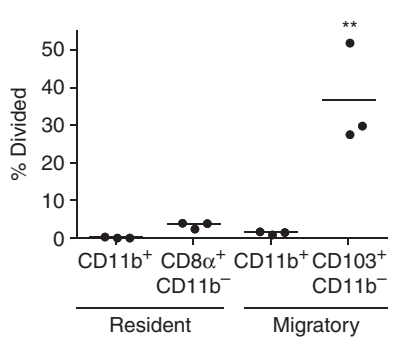

e
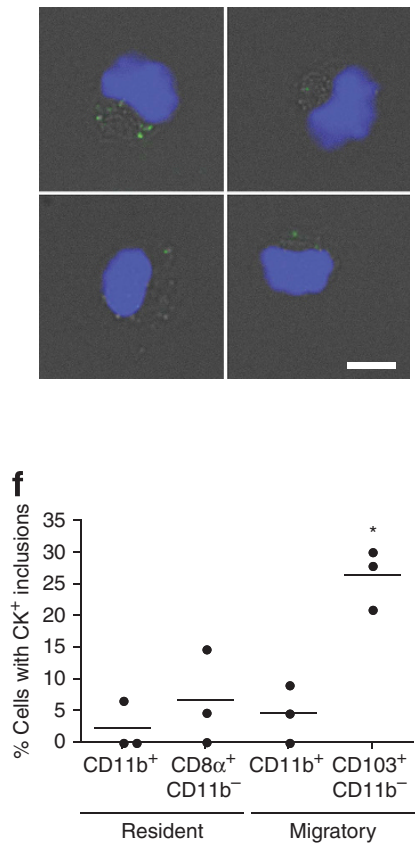

Figure 3 Intestinal epithelial-cell-expressed ovalbumin is cross-presented by migrating CD103 ${ }^{+} \mathrm{CD}_{11 \mathrm{~b}}{ }^{-}$mesenteric lymph node dendritic cells (MLN DCs). (a) Single-cell suspensions of IFABP-tOVA 232-4 mice MLNs were stained for flow cytometry and DC subsets were purified with fluorescence-activated cell sorting as shown. (b) Levels of CD8 $\alpha$ expression were assessed on MLN migratory CD103 ${ }^{+} \mathrm{CD}_{11} \mathrm{~b}^{-} \mathrm{DCs}$ (blue line) and MLN-resident CD11 $b^{-}$DCs (red line). The shaded histogram shows staining of the total MLN DC population with the isotype control antibody. (c,d) $12,500 \mathrm{MLN}$ DCs of the indicated subsets were assessed for their capacity to drive OT-I T-cell proliferation. (c) Histograms represent proliferation as assessed by carboxyfluorescein succinimidyl ester dilution. (d) The graph shows the mean percentage of divided T cells; each dot represents an independent experiment. (e) Cytospins of MLN DC subsets purified as in a were stained with a pan-cytokeratin antibody (green) and DAPI (blue). The images show examples of cytokeratin ${ }^{+}$inclusions within the $\mathrm{CD}_{103^{+}} \mathrm{CD}_{11 \mathrm{~b}^{-}}$migratory MLN DCs. The images show fluorescent signal overlaid on white light images. Bar $=10 \mu \mathrm{m}$. (f) The graph shows the mean percentage of cells of the indicated DC subsets containing visible cytokeratin ${ }^{+}$ cytoplasmic inclusions. In all panels asterisks denote statistical significance $\left({ }^{\star} P<0.05,{ }^{\star \star} P<0.01\right)$. MHC II, major histocompatibility complex class II molecules.

in the peripheral inguinal LNs of the same mice (data not shown).

Next, we examined whether the $\mathrm{T}$ cells activated by the $\mathrm{CD}_{103}{ }^{+} \mathrm{CD}_{11 b^{-}} \mathrm{CD} 8 \alpha^{+} \mathrm{LDC}$ in vivo acquired the characteristic gut-homing phenotype induced by intestinal and MLN DCs. ${ }^{10,23,24}$ Indeed, proliferating CD8 ${ }^{+}$T cells in the MLNs showed increased expression of CCR9, an intestinal homing chemokine receptor (Figure 5b). Furthermore, $\mathrm{CCR}^{+} \mathrm{CFSE}^{\mathrm{dim}}$ transferred $\mathrm{CD} 8^{+}$OT-I $\mathrm{T}$ cells were readily detectable in the small intestinal LP of mice that had received $\mathrm{CD} 103^{+} \mathrm{CD} 11 \mathrm{~b}^{-} \mathrm{CD} 8 \alpha^{+}$, but not in recipients of other LDC subsets (Figure 5c). These data conclusively demonstrate that the $\mathrm{CD} 103^{+} \mathrm{CD}_{11 b^{-}} \mathrm{CD} 8 \alpha^{+}$subset of migrating intestinal DCs is the only migratory DC population capable of cross-presenting IEC-derived antigen to naïve MLN $\mathrm{CD}^{+}{ }^{+} \mathrm{T}$ cells in vivo.

\section{After activation with a TLR7 agonist, migratory intestinal $\mathrm{CD} 103^{+} \mathrm{CD}^{-11 b}{ }^{-} \mathrm{CD} 8 \alpha^{+}$DCs induce effector CD8 ${ }^{+} \mathrm{T}$-cell responses to IEC-derived antigen}

We next examined whether the same subset of intestinal DCs is also responsible for cross-priming CTL responses to IEC-derived antigen under inflammatory conditions. Our data clearly indicate that, in the steady state, migratory $\mathrm{CD} 103^{+}$ $\mathrm{CD} 11 \mathrm{~b}^{-} \mathrm{CD} 8 \alpha^{+}$LDCs are the only cells able to cross-present IEC-derived antigen to OT-I T cells. It is possible that other DC populations may acquire cross-presenting and cross-priming capacities following activation. ${ }^{25,26}$ Indeed it has been proposed that LP-derived intestinal CD $8 \alpha^{-}$DCs are more efficient than $\mathrm{CD} 8 \alpha^{+}$DCs at inducing CTL responses to soluble antigen after TLR activation. ${ }^{11}$ To examine whether the ability to initiate cross-priming of $\mathrm{CD} 8{ }^{+} \mathrm{T}$-cell responses to IEC-derived antigen remained restricted to the $\mathrm{CD} 103^{+} \mathrm{CD} 11 \mathrm{~b}^{-} \mathrm{CD} 8 \alpha^{+}$subset of LDCs under inflammatory conditions, LDCs were isolated from 232-4 mice after a single intraperitoneal dose of R848. $\mathrm{CD}_{103}{ }^{+} \mathrm{CD}_{11 \mathrm{~b}}{ }^{-} \mathrm{CD} 8 \alpha^{+} 232-4$ LDCs or LDCs depleted of this subset were then purified and injected subcapsularly into the MLNs of wild-type recipients of OT-I cells.

As in steady state, the subcapsular transfer of $\mathrm{CD}_{103}{ }^{+}$ $\mathrm{CD}_{11 \mathrm{~b}} \mathrm{C}^{-} \mathrm{CD} 8 \alpha^{+}$LDCs induced marked proliferation of OT-I cells in the recipient MLNs, whereas LDCs that had been depleted of the $\mathrm{CD} 103^{+} \mathrm{CD} 11 \mathrm{~b}^{-} \mathrm{CD} 8 \alpha^{+}$subset were unable to induce OT-I proliferation (Figure 6a). The $\mathrm{CD}_{103}{ }^{+}$ $\mathrm{CD}_{11 \mathrm{~b}}{ }^{-} \mathrm{CD} 8 \alpha^{+}$LDCs from R848-treated 232-4 mice also induced IFN- $\gamma$ production from the dividing OT-I T cells, although no IFN- $\gamma$ was detected after transfer of LDCs depleted 
of this subset (Figure 6b). Importantly, despite inducing $\mathrm{CD} 8^{+}$ T-cell proliferation in vivo, $\mathrm{CD}_{103}{ }^{+} \mathrm{CD}_{11 \mathrm{~b}}{ }^{-} \mathrm{CD} 8 \alpha^{+} \mathrm{DCs}$ from control 232-4 mice that did not receive R848 were also unable to drive the production of IFN- $\gamma$ from transferred OT-I T cells (Figure $\mathbf{6 b}$ ). These results demonstrate that activation of $\mathrm{CD} 8 \alpha^{+}$LDCs by a TLR agonist allows them to prime effector $\mathrm{CD}^{+}{ }^{+} \mathrm{T}$ cells. In contrast, despite stimulation with a TLR agonist, the $\mathrm{CD} 8 \alpha^{-}$LDC subsets were unable to cross-present IEC antigen or induce $\mathrm{CD}^{+}{ }^{+} \mathrm{T}$-cell effector differentiation, indicating that they are not involved in cross- presentation or induction of CTL responses. Finally, as in the steady state, transferred OT-I T cells were only observed in the intestinal LP of mice that had received subcapsular CD8 $\alpha^{+}$ LDCs (Figure 6c).

Taken together, our results demonstrate that, unlike soluble antigen, intestinal cellular antigen is transported and crosspresented to MLN CD8 ${ }^{+} \mathrm{T}$ cells in vivo by a single subset of intestinal DCs, defined by their $\mathrm{CD} 103^{+} \mathrm{CD} 11 \mathrm{~b}^{-} \mathrm{CD} 8 \alpha^{+}$ phenotype, both in the steady state and after TLR7-induced activation.
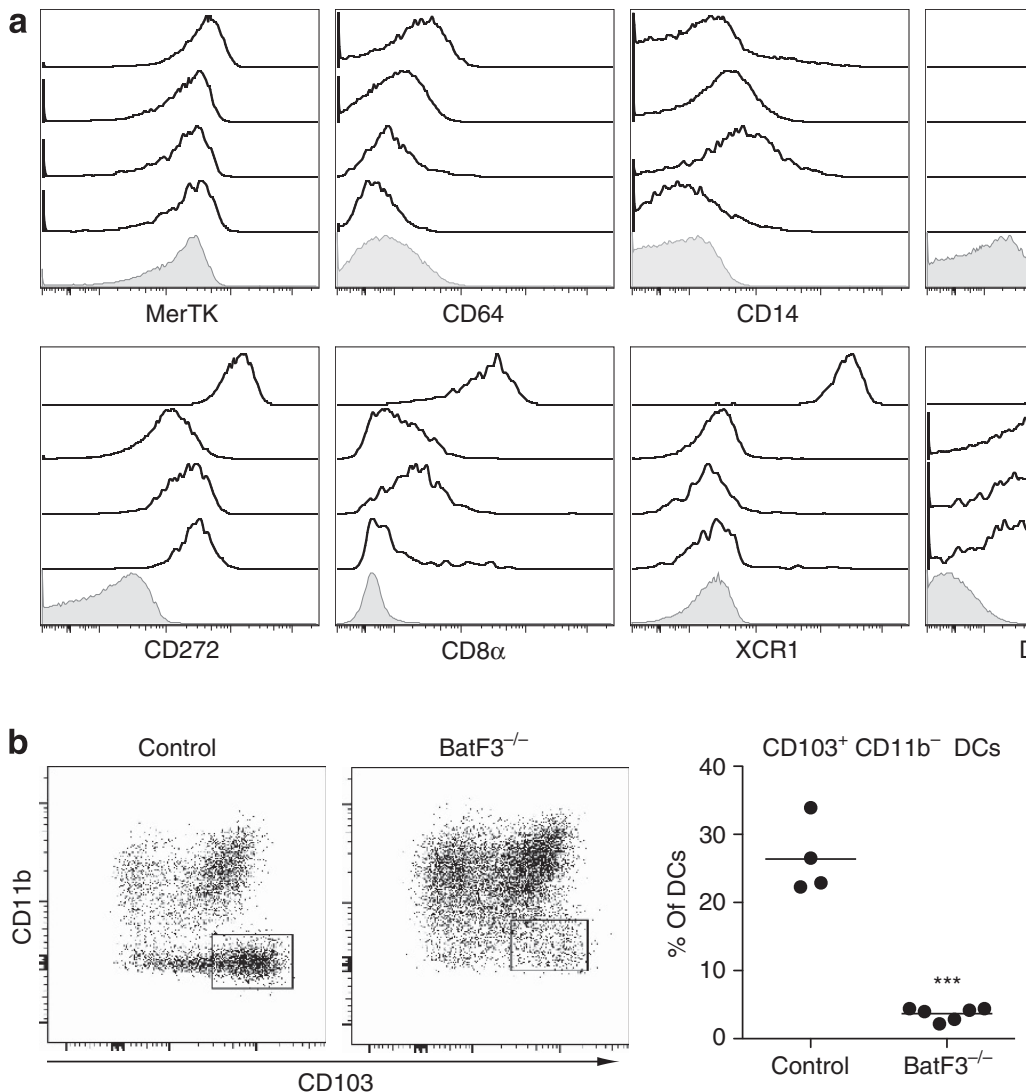

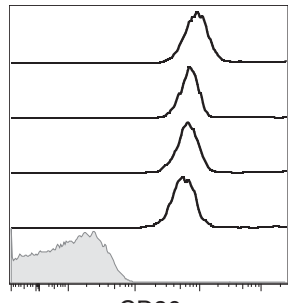

CD26

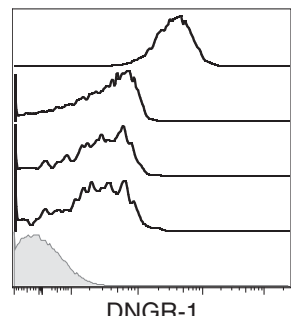

C

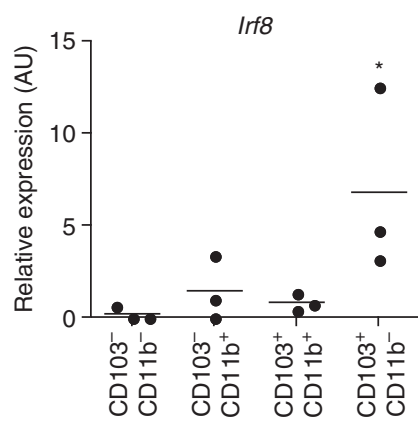

Figure 4 Characteristics of intestinal lymph CD $8 \alpha^{+}$dendritic cells (DCs). (a) Thoracic duct lymph cells from mesenteric lymphadenectomized (MLNx) C57BI6 mice were stained for flow cytometry with phenotypic markers: MerTK, CD64, CD14, CD26, CD24, CD272, CD8 $\alpha$, XCR1, DNGR-1 (Clec-9a), and CD172a. Each plot shows staining of the four lymph DC (LDC) subsets and is representative of at least three independent replicates. The shaded histograms show staining of the total LDC population with the isotype control antibody. (b) Thoracic duct lymph was collected from MLNx Batf $^{-1-}$ mice, and lymph cells were stained for flow cytometry. Dot plots show staining of LDC subsets. The graph shows the proportion of the CD103 ${ }^{+}$ CD11b- DC subset as a percentage of total LDCs. Each dot represents an independent replicate. (c) LDC subsets were purified with fluorescenceactivated cell sorting, the RNA extracted and reverse transcribed into cDNA. Expression of the IRF-8 mRNA was assessed by quantitative PCR. Results presented in arbitrary units $(\mathrm{AU})$, normalized to the housekeeping gene cyclophilin $\mathrm{A}$. In all panels asterisks denote statistical significance $\left({ }^{\star} P<0.05\right.$, $\left.{ }^{* * *} P<0.001\right)$.

Figure 5 Only intestinal lymph $\mathrm{CD}_{103^{+}} \mathrm{CD} 11 \mathrm{~b}^{-} \mathrm{CD} 8 \alpha^{+}$dendritic cells (DCs) cross-present intestinal epithelial cell antigen in vivo. (a) Schematic shows the experimental protocol. Five days after subcapsular injections of 50,000 fluorescence-activated cell sorting (FACS) purified lymph DC (LDC) subsets, mesenteric lymph nodes (MLNs) and the small intestine (SI) were harvested from recipient mice. Cells were then stained for flow cytometry. Transferred OT-I T cells were identified as CD8 ${ }^{+}$CD $45.1^{+} \mathrm{TCR} \mathrm{V} \alpha 2^{+}$in the MLNs (b) or SI lamina propria (LP) (c), and assessed for proliferation by carboxyfluorescein succinimidyl ester (CFSE) dilution. (b) For each injected LDC subset, FACS plots show the relative proportion of transferred OT-I T cells (CD45.1 $1^{+} \mathrm{CD}^{+}$) among TCRV $\alpha 2^{+}$cells (top left), CFSE dilution (top right), and CCR9 expression (bottom left) in the MLNs. The graph shows mean percentage of divided T cells; each dot represents an independent experiment. Asterisks denote statistical significance $\left({ }^{* *} P<0.01\right)$. (c) FACS plots show the relative proportion of transferred OT-I T cells among TCR V $\alpha 2^{+}$cells (left) or CFSE dilution and CCR9 expression of transferred OT-I cells (right) in the LP, and are representative of two independent experiments. i.v., intravenous. 
a

$\mathrm{CD}_{103^{-} \mathrm{CD} 11 \mathrm{~b}^{-}}$

$\mathrm{CD}_{103^{-}} \mathrm{CD}_{11 \mathrm{~b}^{+}}$232-4

\begin{tabular}{ll|l} 
& $\mathrm{CD} 103^{+} \mathrm{CD}_{11 \mathrm{~b}^{+}}$ & LDCs \\
CD45.1 OT-I (CFSE) & $\mathrm{CD}^{+} 03^{+} \mathrm{CD} 8 \alpha^{+}$ &
\end{tabular}

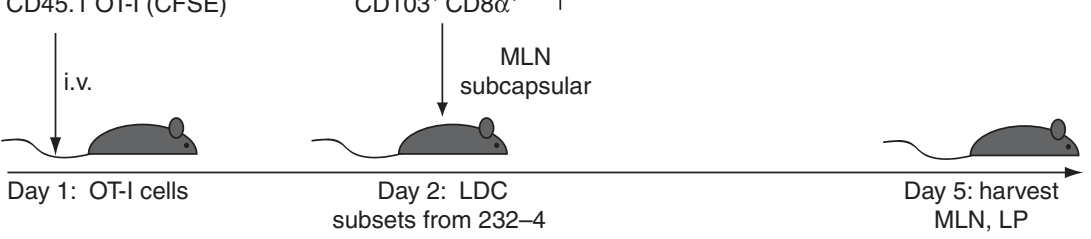

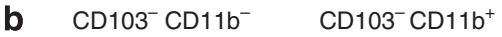

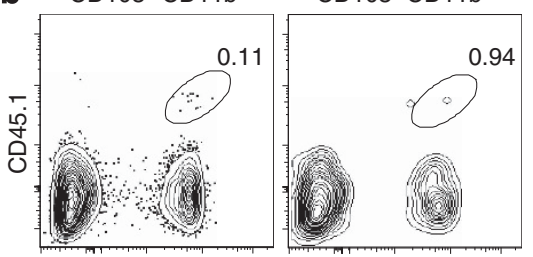

$\mathrm{CD} 103^{-} \mathrm{CD}^{-11 b^{-}} \quad \mathrm{CD}^{-} 3^{-} \mathrm{CD}^{-} 1 \mathrm{~b}^{+}$
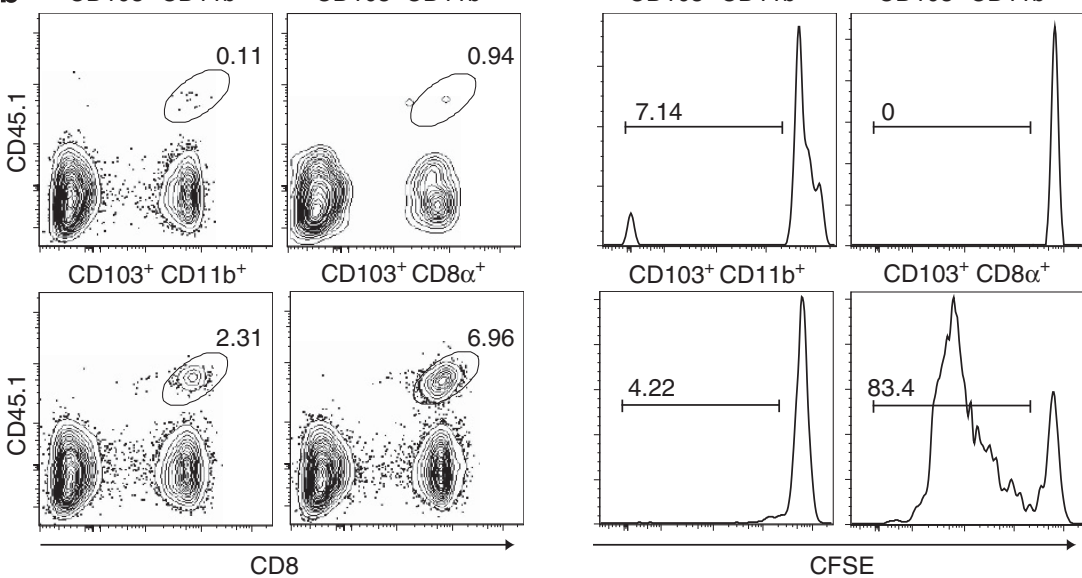

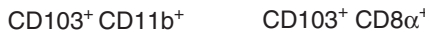
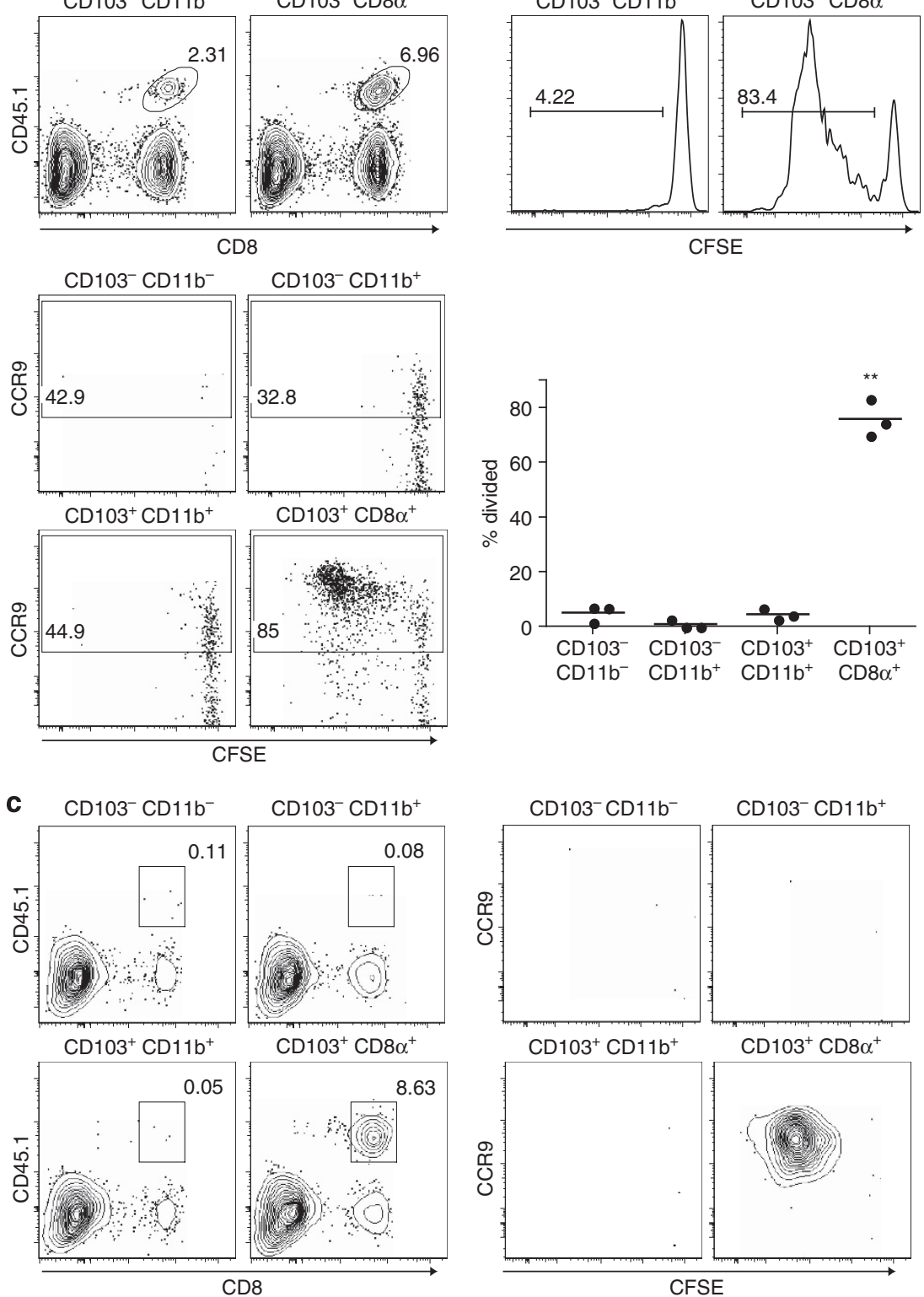

Figure 5 For caption see page 43. 
a
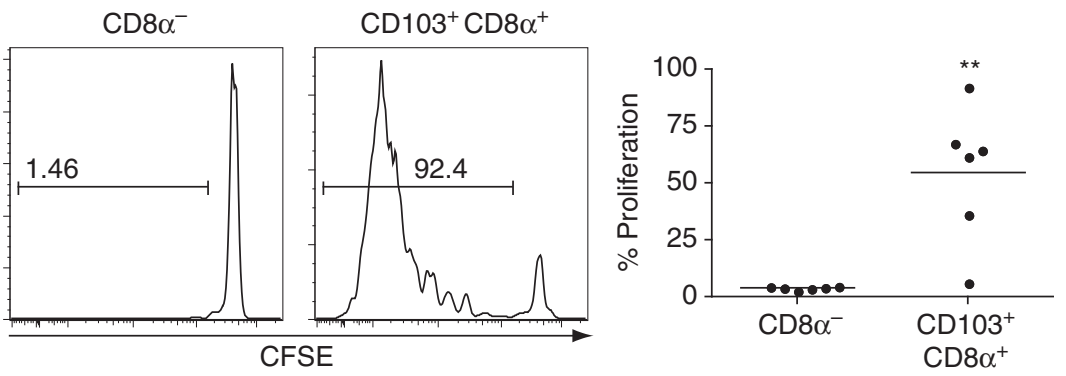

b

$+\mathrm{R} 848$

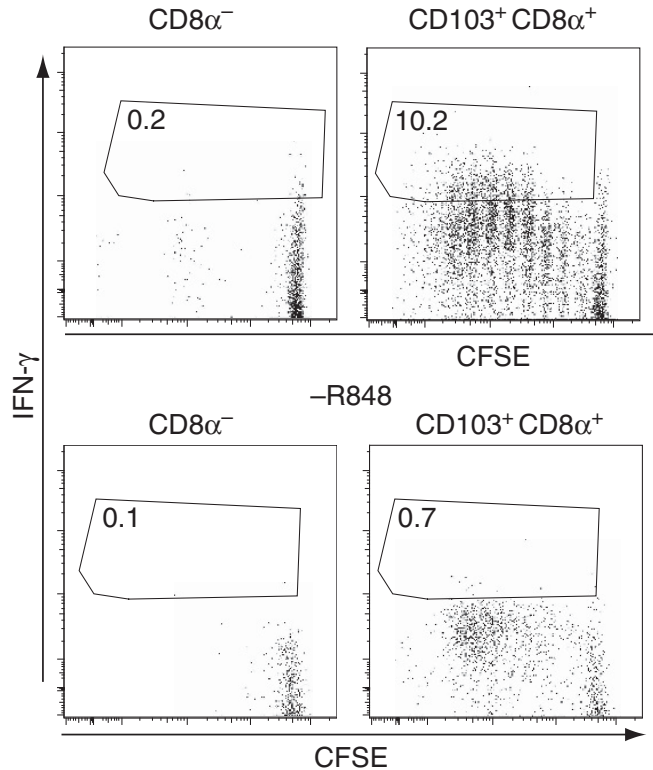

Isotype

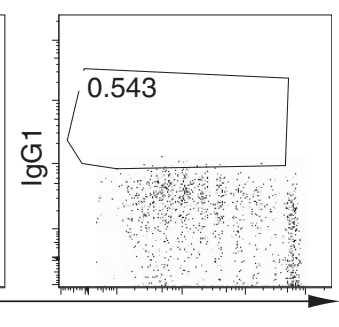

C

$+\mathrm{R} 848$
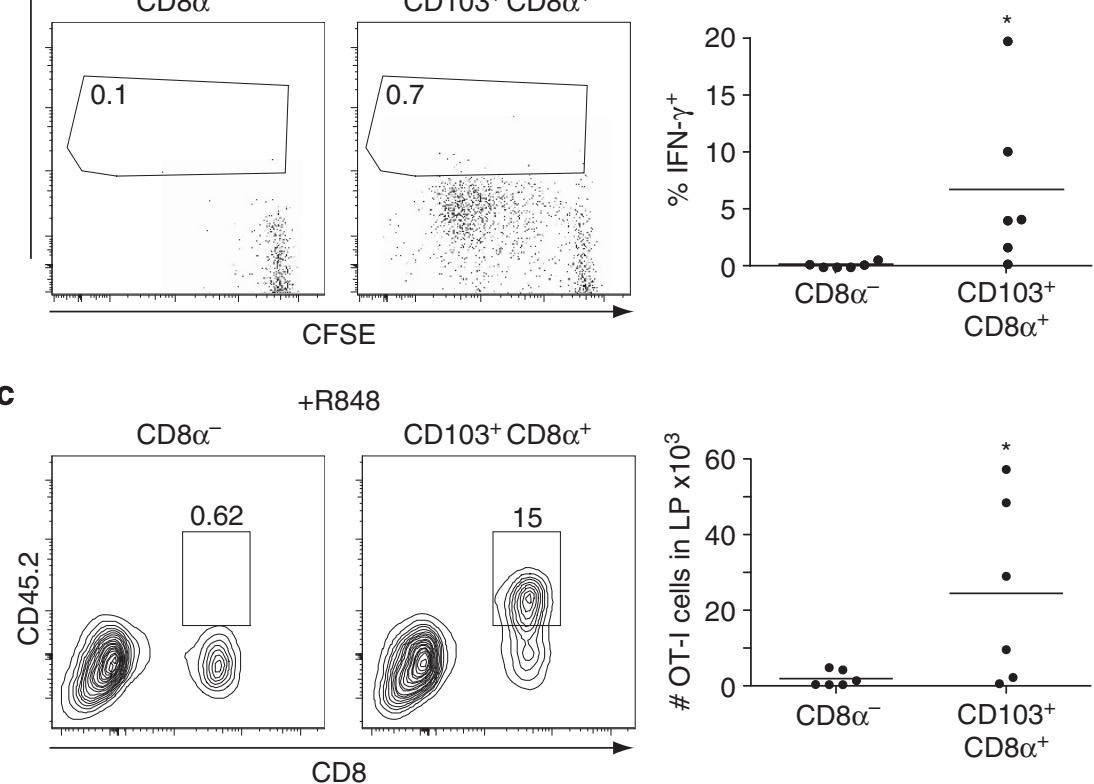

Figure 6 Activated intestinal lymph CD8 $\alpha^{+}$dendritic cells (DCs) cross-prime effector CD8 ${ }^{+} \mathrm{T}$ cells. CD45.1 ${ }^{+}$C57BI6 mice received $5 \times 10^{6}$ carboxyfluorescein succinimidyl ester (CFSE)-labeled CD45.2 $2^{+}$OT-I cells intravenously and, a day later, a subcapsular mesenteric lymph node (MLN) injection of $50,000 \mathrm{CD}_{103}{ }^{+} \mathrm{CD} 8 \alpha^{+}$or CD8 $\alpha^{-}$lymph DCs (LDCs) isolated from R848-treated IFABP-tOVA 232-4 mice. Three days later, MLNs and small intestine (SI) were removed and analyzed by flow cytometry. Transferred T cells were identified as CD ${ }^{+}$CD $45.2^{+}$TCR V $\alpha 2^{+} .(a)$ Histograms show the CFSE dilution of transferred OT-I cells in the MLNs following subcapsular transfer of the indicated LDC subsets. The graph shows the mean percentage of divided cells. (b) Dot plots show representative staining for intracellular interferon $\gamma$ (IFN- $\gamma$ ) on donor OT-I cells in the MLNs. The graph shows the mean percentage of IFN- $\gamma^{+}$cells among transferred OT-I cells. (c) FACS plots show the proportion of transferred OT-I T cells (CD45.2 ${ }^{+}$ $\mathrm{CD}^{+}$) among TCRV $\alpha 2^{+}$cells in the SI lamina propria (LP). The graph shows the mean number of transferred cells in the SI LP. In all graphs, each dot represents an independent biological replicate, and asterisks denote statistical significance $\left({ }^{\star} P<0.05,{ }^{\star \star} P<0.01\right)$.

\section{DISCUSSION}

Cross-presentation of cellular antigens by DCs is crucial for the priming of CTLs capable of killing tumors or virally infected cells. However, the identity of the DCs responsible for crosspresentation in the intestinal mucosa is unclear; several subtypes of intestinal DCs and macrophages are able to cross-present soluble antigen. ${ }^{8,11,27}$ By isolating DCs directly from lymph, we were able to analyze the function of all the DC populations that migrate from the intestine to the MLNs. All four subsets of migrating intestinal DCs can induce proliferation of antigen-specific OT-I CD8 ${ }^{+} \mathrm{T}$ cells in response to soluble antigen. However, to understand how $\mathrm{CD}^{+}$T-cell 
responses against viral and tumor antigens are initiated, it is important to understand which DCs present peripheral cellular antigens to $\mathrm{CD}^{+} \mathrm{T}$ cells. We therefore assessed the crosspresentation capacity of migratory DCs isolated from transgenic 232-4 mice, which express OVA exclusively in small intestinal IECs. ${ }^{14}$ In this system, without the addition of any soluble antigen, only the $\mathrm{CD} 103^{+} \mathrm{CD} 11 \mathrm{~b}^{-} \mathrm{CD} 8 \alpha^{+} \mathrm{LDCs}$, but not the other LDC subsets, were able to induce proliferation and differentiation of naïve OVA-specific $\mathrm{CD} 8^{+} \mathrm{T}$ cells in vitro.

We show further that cross-presentation does not involve the transfer of antigens to resident $\mathrm{CD} 8 \alpha^{+}$DCs in the draining LNs, as has been suggested in other systems, ${ }^{5}$ as the only DCs from 232-4 MLNs capable of priming $\mathrm{CD}^{+} \mathrm{T}$ cells were $\mathrm{CD}_{103}{ }^{+} \mathrm{CD}_{11 \mathrm{~b}^{-}}$migratory DCs. All other MLN DC populations, including the $\mathrm{CD} 8 \alpha^{\text {hi }}$-resident DCs, were completely unable to cross-present IEC antigen. It is therefore unlikely that antigen transfer from migratory to resident DCs plays a major role in the cross-presentation of IEC-derived cellular antigens during the induction phase of the response. As has been indicated previously, ${ }^{10,28}$ we confirm that migrating $\mathrm{CD}_{103}{ }^{+} \mathrm{CD}_{11 \mathrm{~b}^{-}}$also express $\mathrm{CD} 8 \alpha$, but at a lower level than resident MLN DCs.

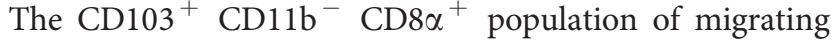
intestinal DCs shares the Batf3 and IRF-8-dependent ontogeny with cross-presenting populations in both lymphoid and peripheral organs, ${ }^{16}$ and expresses a very high level of surface expression of XCR1, a chemokine receptor associated with cross-presentation in mice and human DC subsets. ${ }^{21,22}$ Notably, the cross-presenting population of CD103 ${ }^{+} \mathrm{CD} 8 \alpha^{+}$ DCs were the only subset of DCs migrating in mouse lymph that lacked the expression of $\operatorname{CD} 172 \mathrm{a}(\operatorname{SIRP} \alpha)$. This is consistent with previous evidence that an analogous population of CD103 ${ }^{+} \mathrm{CD} 172 \mathrm{a}^{-}$LDCs in rat lymph can take up apoptotic IECs and transport them to MLNs. ${ }^{18}$ In line with this, CD103 ${ }^{+}$ CD11b ${ }^{-}$CD8 $\alpha^{+}$LDCs express DNGR-1 (Clec-9a), which is involved in the uptake of dead cells and is expressed on crosspresenting populations in mice and humans. ${ }^{19,20}$ Furthermore, $\mathrm{CD}_{103}{ }^{+} \mathrm{CD}_{11 \mathrm{~b}}{ }^{-}$DCs that migrate from the lung selectively sample apoptotic cell antigen. ${ }^{6}$ Thus, it is highly likely that intestinal CD $103^{+} \mathrm{CD}_{11 \mathrm{~b}}{ }^{-} \mathrm{CD} 8 \alpha^{+}$DCs and other migratory $\mathrm{CD}_{11 \mathrm{~b}}{ }^{-}$DCs utilize similar mechanisms to sample cellular material, transport it to LNs, and present it to $\mathrm{CD} 8{ }^{+} \mathrm{T}$ cells.

It has been suggested that $\mathrm{CD}_{103}{ }^{+} \mathrm{CD} 1 \mathrm{~b}^{-}$intestinal DCs mainly derive from the lymphoid tissues of the intestine, such as Peyer's patches or isolated lymphoid follicles. However, we have previously shown that these cells are present in normal numbers in the intestine and lymph of mice lacking all lymphoid tissues, ${ }^{10}$ suggesting that they mainly derive from the LP. Further characterization of this LDC subset, including the expression of DNGR-1 and XCR1, support this interpretation; DCs expressing DNGR-1 (Clec-9a) can be found throughout human non-lymphoid tissues, including the LP, where they can be observed in the immediate vicinity of the intestinal

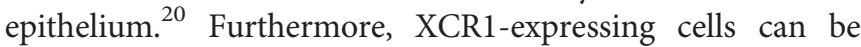
observed throughout the LP of the small intestinal villi (Richard Kroczek, unpublished data) as well as in other non-lymphoid tissues. ${ }^{21}$ Although we cannot rule out the possibility that some $\mathrm{CD}_{103}{ }^{+} \mathrm{CD}_{11 \mathrm{~b}}{ }^{-} \mathrm{CD} 8 \alpha^{+}$LDCs originate in the lymphoid compartments of the intestine, it is likely that they largely represent LP-derived migratory DCs.

Crucially, $\mathrm{CD} 103^{+} \mathrm{CD} 1 \mathrm{~b}^{-} \mathrm{CD} 8 \alpha^{+}$DCs are also able to cross-present IEC antigen to $\mathrm{CD} 8{ }^{+} \mathrm{T}$ cells in vivo. By adapting a technique described by the Pabst laboratory, ${ }^{29}$ we showed that subcapsular injection of $\mathrm{CD} 103^{+} \mathrm{CD} 11 \mathrm{~b}^{-} \mathrm{CD} 8 \alpha^{+}$LDCs, but not other DC subsets, from the lymph of steady-state 232-4 mice into the MLNs led to clonal expansion of OT-I T cells.

The capacity of intestinal DCs to induce gut tropism in a retinoic acid-dependent manner has been well characterized. $^{24,30}$ However, it is not clear which intestinal DCs are primarily responsible for inducing this phenotype in $\mathrm{CD}^{+}{ }^{+} \mathrm{T}$ cells. In contrast with an earlier report, ${ }^{11}$ we have recently shown that $\mathrm{CD} 103^{+} \mathrm{CD} 11 \mathrm{~b}^{-} \mathrm{CD} 8 \alpha^{+}$DCs have high aldehyde dehydrogenase activity and can induce CCR9, a marker of gut tropism on T cells, with a similar efficiency to the other intestinal DC subsets. ${ }^{10}$ Here we show that, in vivo, crosspresentation by $\mathrm{CD} 103^{+} \mathrm{CD} 11 \mathrm{~b}^{-} \mathrm{CD} 8 \alpha^{+}$DCs also induces CCR9 expression on responding OT-I T cells, and that, in this experimental system, fully differentiated CCR9 ${ }^{+}$OT-I cells are only detectable in the intestinal LP of mice after subcapsular injection of $\mathrm{CD}_{103}{ }^{+} \mathrm{CD} 11 \mathrm{~b}^{-} \mathrm{CD} 8 \alpha^{+}$LDCs, but not other LDC subsets.

Subcapsular transfer of steady-state $\mathrm{CD}_{103}{ }^{+} \mathrm{CD}_{11 \mathrm{~b}}{ }^{-}$ CD $8 \alpha^{+}$LDCs causes T-cell proliferation, but does not induce production of IFN- $\gamma$. This replicates the phenotype of OT-I cells transferred to 232-4 mice, which remain tolerant to OVAexpressing IEC under steady-state conditions but, as we show here, develop into CTLs when challenged with the TLR7 agonist R848. Importantly, CD103 ${ }^{+} \mathrm{CD}_{11 b^{-}} \mathrm{CD} 8 \alpha^{+}$DCs isolated from the lymph of 232-4 mice treated with R848 are sufficient to induce differentiation of $\mathrm{CD} 8{ }^{+} \mathrm{T}$ cells into IFN- $\gamma$-producing gut-tropic $\mathrm{T}$ cells after subcapsular transfer into MLNs. In addition, despite the suggestion that other DC populations may acquire cross-presenting and cross-priming capacities following activation, ${ }^{11,25,26}$ LDCs depleted of the $\mathrm{CD} 8 \alpha^{+}$subset were unable to cross-present IEC antigen.

Taken together, these data definitively demonstrate that the migrating $\mathrm{CD} 103^{+} \mathrm{CD} 11 \mathrm{~b}^{-} \mathrm{CD} 8 \alpha^{+}$DCs play an essential and exclusive role in the initial cross-presentation of cellular antigens to naive $\mathrm{CD} 8{ }^{+}$OT-I T cells in the MLNs and can, in the presence of an inflammatory stimulus, initiate the differentiation of IFN- $\gamma^{+}$effector $\mathrm{CD}^{+}$T cells.

Our results suggest that plasticity of $\mathrm{CD}_{103}{ }^{+} \mathrm{CD} 11 \mathrm{~b}^{-}$ $\mathrm{CD} 8 \alpha^{+}$intestinal DCs is the crucial mechanism that controls the balance between $\mathrm{CD} 8{ }^{+} \mathrm{T}$-cell-dependent homeostasis and active immunity. Like other DCs, $\mathrm{CD} 103^{+} \mathrm{CD} 11 \mathrm{~b}^{-} \mathrm{CD} 8 \alpha^{+}$ appear to be exquisitely sensitive to their environment. They maintain tolerance under steady-state conditions, but react to stimuli such as TLR ligands, and drive the generation of effector $\mathrm{CD} 8{ }^{+} \mathrm{T}$ cells. Selective targeting of these processes in migratory $\mathrm{CD} 103^{+} \mathrm{CD}_{11} \mathrm{~b}^{-} \mathrm{CD} 8 \alpha^{+}$DCs may be a productive strategy for the generation of novel vaccines against mucosal pathogens. 


\section{METHODS}

Animals. C57/Bl6 mice were purchased from Harlan and maintained in individually ventilated cages. 232-4 IFABP-tOVA mice (a kind gift from Professor Leo LeFrancois, University of Connecticut) and OT-I mice were bred and maintained under specific pathogen-free conditions at the Central Research Facility, Glasgow. All protocols involving live animals were approved by the local ethical committee and conducted under licenses issued by the UK Home Office. Batf $3^{-1-}$ mice were bred in specific pathogen-free conditions at the Experimental Biomedicine Animal Facility, University of Gothenburg.

Surgical procedures. Mesenteric lymphadenectomy and thoracic duct cannulation procedures were performed according to established protocols. ${ }^{10}$ Mesenteric lymphadenectomy was performed on 6-weekold C57/Bl6 or 232-4 male mice by laparotomy and blunt dissection. Six weeks later, mice were fed $0.2 \mathrm{ml}$ olive oil to visualize the lymphatics and the thoracic lymph duct was cannulated by the insertion of a polyurethane cannula (2Fr, Linton Instrumentation, Diss, UK). Lymph was collected in phosphate-buffered saline with $20 \mathrm{U} \mathrm{ml}^{-1}$ of heparin sodium (Wockhardt UK, Wrexham, UK), on ice, for up to 16h. Subcapsular MLN injections of cells were adapted from a technique for intralymphatic injections. ${ }^{29}$ Briefly, cells were resuspended in $<10 \mu \mathrm{l}$ of saline and injected into the subcapsular lymph sinus of the MLNs, using a BD Micro-Fine 30G needle (BD Biosciences, Oxford, UK). During surgical procedures the animals were maintained under inhalation anesthesia with isoflurane (Abbott Animal Health, Abbott Park, IL).

Generation of bone marrow chimeras. Eight-week-old mice received a lethal dose of radiation $(10 \mathrm{~Gy})$ and were reconstituted with $5 \times 10^{6}$ bone marrow cells by intravenous injection. Six weeks later, MLNs were harvested for DC isolation.

Reagents. Cells were cultured in RPMI 1640, supplemented with $100 \mathrm{U} \mathrm{ml}^{-1}$ penicillin, $100 \mu \mathrm{g} \mathrm{ml}^{-1}$ streptomycin, $2 \mathrm{mM}$ L-glutamine, $5 \%$ fetal calf serum (all from Invitrogen, Paisley, UK), and $50 \mu \mathrm{M}$ 2-mercaptoethanol (2-ME; Sigma-Aldrich, St Louis, MO). Intraperitoneal injections of $10 \mu \mathrm{g}$ of R848 (Resiquimod; Invivogen, San Diego, CA) were used to activate DCs in vivo.

Antibodies. Fluorochrome-conjugated monoclonal antibodies to mouse antigens: TCRV $\alpha 2$ (B20.1), CD11b (M1/70), CD11c (N418), CD24 (30-F1), CD26 (H194-112), CD45 (30-F11), CD45.1 (A20), CD45.2 (104), B220 (RA3-6B2), CD62L (MEL-14), CD64 (X54-5/7.1), CD103 (2E7), CLEC9A (7H11), and CCR9 (CW-1.2) were purchased from BioLegend (San Diego, CA). Monoclonal antibodies to mouse CD8 $\alpha$ (53-6.7), CD172a (P84), and IFN- $\gamma$ (XMG1.2) were from BD Biosciences (Oxford, UK). The I-A/I-E MHCII (M5/114.15.2), CD14 (Sa2-8), and CD272 (6F7) antibodies were purchased from eBioscience (San Diego, CA). Biotinylated antibody to mouse MerTK (BAF591) was purchased from R\&D Systems (Minneapolis, MN). XCR1 mAb (MARX-10) was generated as described. ${ }^{22}$ The 7AAD dead cell exclusion dye, streptavidin reagents, and mouse isotype control antibodies, conjugated to appropriate fluorochromes, were purchased from BioLegend.

Cell isolation. Thoracic duct leukocytes were collected on ice in phosphate-buffered saline with $20 \mathrm{U} \mathrm{ml}^{-1}$ heparin, passed through a $40-\mu \mathrm{m}$ cell strainer (BD Biosciences), and RBCs lysed with ACK (ammonium-chloride-potassium) lysis buffer (Sigma-Aldrich). Cells were stained and analyzed by flow cytometry or sorted by fluorescenceactivated cell sorting using the FACSAria cell sorter (BD Biosciences).

Small intestines were flushed with Hank's balanced salt solution with $2 \%$ fetal calf serum and the Peyer's patches excised. The intestines were opened longitudinally and cut into $0.5-\mathrm{cm}$ segments, which were incubated twice in Hank's balanced salt solution with 2-mM ethylenediaminetetraacetic acid at $37^{\circ} \mathrm{C}$ while shaking for $20 \mathrm{~min}$. Supernatants were discarded and the tissue digested with $1 \mathrm{mg} \mathrm{ml}^{-1}$ of collagenase VIII (Sigma-Aldrich) at $37^{\circ} \mathrm{C}$ with shaking for $15 \mathrm{~min}$.
MLNs were macerated and incubated with 0.4 Wunsch units per milliliter of Blendzyme and $50 \mu \mathrm{g} \mathrm{ml}^{-1}$ of DNAse (both from Roche, Penzberg, Germany) for $45 \mathrm{~min}$ at $37^{\circ} \mathrm{C}$ while shaking. Single-cell suspensions were passed through a $40-\mu \mathrm{m}$ cell strainer and stained for flow cytometry.

Flow cytometry. Cell surface staining was performed in phosphatebuffered saline with $2 \%$ fetal calf serum and $10 \mathrm{~mm}$ ethylenediaminetetraacetic acid for $30 \mathrm{~min}$ on ice. Where biotin-conjugated antibody was used, cells were further stained with a streptavidin-fluorochrome conjugate for $15 \mathrm{~min}$. Samples were acquired on LSRII (BD Biosciences) or MACSQuant (Miltenyi Biotec) flow cytometers, or sorted and analyzed by the FACSAria cell sorter (BD Biosciences). For intracellular cytokine staining, cells were incubated for $4 \mathrm{~h}$ with phorbol 12-myristate 13-acetate, ionomycin, brefeldin $\mathrm{A}$, and monensin (all from eBioscience). Cells were stained for surface marker expression and washed. Cells were then fixed in $4 \%$ paraformaldehyde, permeabilized, and stained for intracellular cytokine. Acquired data were analyzed using FlowJo software (version 9.3.1; Tree Star, Ashland, OR)

Microscopy. Dissected tissues were immediately fixed in neutral buffered formalin. They were embedded in paraffin, sectioned $(5 \mu \mathrm{m})$, and stained with hematoxylin and eosin. Images were obtained using a light microscope at $\times 10$ magnification and were analyzed, and archived using cell^ B software (Olympus, Tokyo, Japan).

For cytospins, cells were centrifuged (300 r.p.m., 5 min) onto poly-Llysine coated slides (VWR International, Radnor, PA), fixed in acetone, and stained with the anti-mouse pan-cytokeratin (C-11; Sigma-Aldrich) or isotype control antibody. Images were obtained using the EVOS Cell Imaging System (Life Technologies).

Proliferation assay. Sorted C57/B16 LDCs were pulsed with $2 \mathrm{mg} \mathrm{ml}^{-1}$ of OVA (Worthington, Lakewood, NJ) for $2 \mathrm{~h}$ at $37^{\circ} \mathrm{C}$ and then extensively washed. They or unpulsed 232-4 LDCs were cultured at varying ratios with $10^{5}$ carboxyfluorescein succinimidyl ester-labeled naive OT-I CD8 ${ }^{+} \mathrm{T}$ cells at $37^{\circ} \mathrm{C}$ for 3 days. Carboxyfluorescein succinimidyl ester dilution was assessed by flow cytometry.

Serum cytokine detection. Serum concentration of IFN- $\gamma$ was assessed by ELISA (enzyme-linked immunosorbent assay; Millipore, Billerica, MA) according to the manufacturer's instructions. Minimum detectable concentration was $<5 \mathrm{pg} \mathrm{ml}^{-1}$.

RNA extraction. RNA was extracted using the MicroRNA kit (Qiagen, Venlo, Netherlands) according to the manufacturer's instructions. Contaminating genomic DNA was removed using the DNA-free kit (Qiagen). RNA was reverse transcribed using the Superscript First Strand kit (Invitrogen).

Real-time quantitative PCR. cDNA was examined for the frequency of the Irf 8 transcript by quantitative real-time PCR using the Brilliant III Ultra Fast SYBR qPCR master mix (Agilent Technologies, Santa Clara, CA). Fluorescence levels were detected and analyzed using the 7900HT Fast system (Applied Biosystems). Relative quantification was determined using the $\Delta \Delta \mathrm{Ct}$ method and normalized to expression of the housekeeping gene cyclophilin A.

Primers used were cyclophilin A: forward $5^{\prime}$-GTGGTCTTTG GGAAGGTGAA-3' ${ }^{\prime}$, reverse 5' ${ }^{\prime}$ TTACAGGACATTGCGAGCAG- ${ }^{\prime}$; IRF8: forward 5'-GAGCGAAGTTCCTGAGATGG, reverse 5' -TGGG CTCCTCTTGGTCATAC-3'.

Statistical analysis. For comparison of means between two groups, the data were analyzed by Student's $t$-test. For comparisons involving more than two data sets, analysis of variance was used. $P$ values $<0.05$ were considered significant and Bonferroni post-test was performed on the data sets. Unless otherwise stated, asterisks denote significant difference of the indicated group from all other groups. All statistical analysis was performed using GraphPad Prism and Microsoft Excel. 
SUPPLEMENTARY MATERIAL is linked to the online version of the paper at http://www.nature.com/mi

\section{ACKNOWLEDGMENTS}

We would like to thank Leo LeFrancois for the kind gift of IFABP-tOVA 232-4 mice. We would also like to thank Jim Reilly, Shauna Kerr, and the staff of the central research facility for technical assistance, and the University of Glasgow Flow Cytometry Core Facility for assistance with cell sorting. V.C. was funded by a Medical Research Council award (MR/K021095/1) to S.W.F.M.; C.L.S., C.C.B., and A.M.M. were funded by the Wellcome Trust. S.A.H. was supported by a Capacity Building Award in Integrative Mammalian Biology funded by the BBSRC, BPS, KTN, MRC, SFC, AstraZeneca, GlaxoSmithKline, and Pfizer. L.U. was funded by a grant from the Arthritis Research UK to S.W.F.M.

\section{DISCLOSURE}

The authors declare no conflict of interest.

c 2015 Society for Mucosal Immunology

\section{REFERENCES}

1. Haan den, J.M., Lehar, S.M. \& Bevan, M.J. CD8(+) but not CD8(-) dendritic cells cross-prime cytotoxic T cells in vivo. J. Exp. Med. 192 1685-1696 (2000).

2. Iyoda, T. et al. The CD8+ dendritic cell subset selectively endocytoses dying cells in culture and in vivo. J. Exp. Med. 195, 1289-1302 (2002).

3. Bonifaz, L., Bonnyay, D., Mahnke, K., Rivera, M., Nussenzweig, M.C. \& Steinman, R.M. Efficient targeting of protein antigen to the dendritic cell receptor DEC-205 in the steady state leads to antigen presentation on major histocompatibility complex class I products and peripheral CD8 + T cell tolerance. J. Exp. Med. 196, 1627-1638 (2002).

4. Bonifaz, L.C. et al. In vivo targeting of antigens to maturing dendritic cells via the DEC-205 receptor improves T cell vaccination. J. Exp. Med. 199, 815-824 (2004).

5. Allan, R.S. et al. Migratory dendritic cells transfer antigen to a lymph noderesident dendritic cell population for efficient CTL priming. Immunity 25 , 153-162 (2006).

6. Desch, A.N. et al. CD103+ pulmonary dendritic cells preferentially acquire and present apoptotic cell-associated antigen. J. Exp. Med. 208, 1789-1797 (2011).

7. Bedoui, S. et al. Cross-presentation of viral and self antigens by skin-derived CD103 + dendritic cells. Nat. Immunol. 10, 488-495 (2009).

8. Chang, S.Y. et al. Circulatory antigen processing by mucosal dendritic cells controls CD8(+) T cell activation. Immunity 38, 153-165 (2013).

9. Schulz, O. et al. Intestinal CD103 +, but not CX3CR1 +, antigen sampling cells migrate in lymph and serve classical dendritic cell functions. J. Exp. Med. 206, 3101-3114 (2009).

10. Cerovic, V. et al. Intestinal CD103( - ) dendritic cells migrate in lymph and prime effector T cells. Mucosal Immunol. 6, 104-113 (2013).

11. Fujimoto, K. et al. A new subset of $\mathrm{CD} 103+\mathrm{CD} 8$ \{alpha\} + dendritic cells in the small intestine expresses TLR3, TLR7, and TLR9 and induces Th1 response and CTL activity. J. Immunol. 186, 6287-6295 (2011).

12. Jakubzick, C. et al. Lymph-migrating, tissue-derived dendritic cells are minor constituents within steady-state lymph nodes. J. Exp. Med. 205, 2839-2850 (2008).
13. Schulz, O. \& Reis e Sousa, C. Cross-presentation of cell-associated antigens by CD8alpha + dendritic cells is attributable to their ability to internalize dead cells. Immunology 107, 183-189 (2002).

14. Vezys, V., Olson, S. \& Lefrancois, L. Expression of intestine-specific antigen reveals novel pathways of CD8 T cell tolerance induction. Immunity $\mathbf{1 2}$, 505-514 (2000).

15. Vezys, V. \& Lefrançois, L. Cutting edge: inflammatory signals drive organspecific autoimmunity to normally cross-tolerizing endogenous antigen. J. Immunol. 169, 6677-6680 (2002).

16. Edelson, B.T. et al. Peripheral CD103 + dendritic cells form a unified subset developmentally related to CD8alpha + conventional dendritic cells. J. Exp. Med. 207, 823-836 (2010).

17. Satpathy, A.T. etal. Notch2-dependent classical dendritic cells orchestrate intestinal immunity to attaching-and-effacing bacterial pathogens. Nat. Immunol. 14, 937-948 (2013).

18. Huang, F.P. et al. A discrete subpopulation of dendritic cells transports apoptotic intestinal epithelial cells to $T$ cell areas of mesenteric lymph nodes. J. Exp. Med. 191, 435-444 (2000).

19. Poulin, L.F. et al. Characterization of human DNGR-1+ BDCA3+ leukocytes as putative equivalents of mouse CD8alpha + dendritic cells. J. Exp. Med. 207, 1261-1271 (2010).

20. Poulin, L.F. et al. DNGR-1 is a specific and universal marker of mouse and human Batf3-dependent dendritic cells in lymphoid and nonlymphoid tissues. Blood 119, 6052-6062 (2012).

21. Crozat, K. et al. Cutting edge: expression of XCR1 defines mouse lymphoid-tissue resident and migratory dendritic cells of the CD $8 \alpha+$ type. J. Immunol. 187, 4411-4415 (2011).

22. Bachem, A. et al. Expression of XCR1 characterizes the Batf3-dependent lineage of dendritic cells capable of antigen cross-presentation. Front Immunol. 3, 214 (2012).

23. Johansson-Lindbom, B. et al. Functional specialization of gut CD103+ dendritic cells in the regulation of tissue-selective T cell homing. J. Exp. Med. 202, 1063-1073 (2005).

24. Jaensson-Gyllenbäck, E. et al. Bile retinoids imprint intestinal CD103+ dendritic cells with the ability to generate gut-tropic T cells. Mucosal Immunol. 4, 438-447 (2011).

25. Joffre, O.P., Segura, E., Savina, A. \& Amigorena, S. Cross-presentation by dendritic cells. Nat. Rev. Immunol. 12, 557-569 (2012).

26. Datta, S.K. \& Raz, E. Induction of antigen cross-presentation by Toll-like receptors. Springer Semin. Immunopathol. 26, 247-255 (2005).

27. Chung, Y., Chang, J.H., Kweon, M.N., Rennert, P.D. \& Kang, C.Y. CD8alpha-11b + dendritic cells but not CD8alpha + dendritic cells mediate cross-tolerance toward intestinal antigens. Blood 106, 201-206 (2005).

28. Jang, M.H. et al. CCR7 is critically important for migration of dendritic cells in intestinal lamina propria to mesenteric lymph nodes. J. Immunol. 176, 803-810 (2006).

29. Hammerschmidt, S.I. et al. Stromal mesenteric lymph node cells are essential for the generation of gut-homing T cells in vivo. J. Exp. Med. 205, 2483-2490 (2008).

30. Jaensson, E. et al. Small intestinal CD103 + dendritic cells display unique functional properties that are conserved between mice and humans. J. Exp. Med. 205, 2139-2149 (2008).

This work is licensed under the Creative Commons

Works 3.0 Unported License. To view a copy of this license, visit http://creativecommons.org/licenses/by-nc-nd/3.0/ 